\title{
Love and Loss in Wartime: An Unpublished Narrative by Pamela Frankau
}

(1908-67)

\begin{abstract}
This article discusses an unpublished book by the popular and prolific novelist Pamela Frankau (1908-67), which was rejected by her publishers in 1946 as "almost too personal for publication", and which for many years was believed lost. The work is addressed to Frankau's dead lover, Marjorie Vernon Whitefoord (1907-44), a fellow officer in the women's Auxiliary Territorial Service, and takes the form of a letter to Vernon. The article examines what Frankau's unpublished narrative of love and loss in wartime reveals about her life and later novels, and its implications for the official record of her life and writing.
\end{abstract}

Keywords: Pamela Frankau; twentieth-century literature; lesbian relationships in literature; lesbian history; bereavement in literature Short title: An unpublished narrative by Pamela Frankau

On November 12 1946, the popular novelist Pamela Frankau submitted her first book for nearly seven years to her London publishers, William Heinemann. Such a long silence was unprecedented for Frankau: a prolific writer since her late teens, she had published twenty books, including fifteen novels and three 
volumes of short stories, by the age of thirty-two. Her agents clearly expected Heinemann to accept the new work, but the editor Louise Callender responded in some perplexity:

It is a very difficult book to decide about. It is very well written, with sincere emotion; and it is obviously a book which the author had to write. Yet it is so full of the author's personal feelings that I think she may regret publication in a year or so. It is almost too personal for publication. Also, there are many details that cannot be interesting except to the author. But, as I have said, the writing is good, there is excellent shaping, and such sincerity that every one of the author's emotions comes blazing through with the utmost vividness.

I understand that Miss Frankau is writing a novel, and what we should like to suggest is that she put this present book aside - at any rate until the novel is finished - and then consider whether the novel should not be published first. ${ }^{\mathrm{i}}$

Frankau agreed with this judgment and advised that Callender should keep the new book "in cold storage for the moment."ii Rediscovered decades later in Heinemann's basement, Frankau's unpublished narrative is now in the possession of Frankau's nephew and literary executor, Timothy d'Arch Smith.iii The untitled work, a little over 24,000 words long, takes the form of a letter or “one-sided conversation” (Frankau, n.d.: 1). It is addressed to Frankau's dead lover, Marjorie Vernon Whitefoord (1907-44), known as Vernon, an officer in the women's branch of the Army, the Auxiliary Territorial Service. This article 
examines what Frankau's unpublished narrative reveals about her life and writings, and its implications for the official record of both.

Pamela Frankau (1908-67) is probably best known today for her novel The Willow Cabin (1949), reprinted by Virago in 1988 and reissued in 2008. A thirdgeneration novelist from an Anglo-Jewish family (her father, Gilbert Frankau, and grandmother, Julia, who published under the name "Frank Danby", were both well-known and popular writers of fiction), Frankau began making a name for herself with her first book, The Marriage of Harlequin (1927), published when she was nineteen. "You are the third," her agent told her. "And you will be the best" (Frankau, 1935/1938: 117). Diana Raymond's unpublished biography, commissioned by Virago in the 1980s, remains the fullest source of information on Frankau's life (Raymond, n.d.). Raymond, Frankau's cousin as well as her biographer, also composed the Dictionary of National Biography entry on Frankau (Raymond, 2004). Timothy d'Arch Smith's book The Frankaus: Prejudice and Principles within a London Literary Family (d'Arch Smith, 2015) includes some discussion of Frankau's life and work, but focuses more on Gilbert and Julia Frankau.iv I discuss Frankau's work in depth in "A Roller-coaster of a Life with Everything in it: Pamela Frankau (1908-67)” (Gonda, 2009), including a brief account of her unpublished narrative about Vernon.

The narrative spans the period from December 1941, when Frankau first visits Vernon at her Platoon Headquarters in Wales, to Vernon's death from a stroke, exacerbated by drink, in August 1944, and Frankau's experience of grief and mourning in the months that followed. "It's a grey world," Frankau wrote to her 
friend Barbara Armstrong, “but I can't complain: we had such a hell of a good time always" (Raymond, n.d.: 189). The conversational vividness of Frankau's narrative makes both the good time and the grey world sharply present; this is not an easy work to read, or to write about.

Vernon's death was Frankau's second major bereavement in five years. Her long silence as a writer followed the sudden death in January 1940 of Humbert Wolfe, her lover since 1931. Frankau spent some months "going haywire" in the USA (Stern, 1957: 93), drinking heavily and having casual sexual encounters, including what seems to have been her first sexual experience with another woman (Raymond, n.d.: 159). She returned to England in November 1940, at the height of the Blitz, and became a Civil Servant at the Ministry of Food. By December 1941 she was thinking seriously about joining the Army; her discussion with Vernon settled the matter for her.

Frankau applied to join the ATS in February 1942, and the two women became comrades as well as friends. Vernon, a cradle Catholic, was also her sponsor when Frankau was received into the Catholic church in May 1942. From June to December 1942, Frankau spent all her weekends with Vernon, learning ATS administration by observing her at work. At Frankau's urging, Vernon transferred to her specialist branch, Army Education, in the spring of 1943. In autumn 1943 the two women rented a house in London so that they could share a private life: "Behind that door we could be, together or separately, at peace" (Frankau, n.d.: 41). It's not clear at what point they became lovers, though Diana Raymond suggests that Frankau fictionalized part of this process in her novel, 
Shaken in the Wind, where Stuart declares himself to Cynthia by leaving a note in her favorite book of poetry that says "Please love me" (Frankau, 1948: 40). Raymond writes that "those who have talked to Pamela believe that in fact this was the manner of Vernon's first advance. If so, it is easy to understand how Pamela would respond. Easy too to understand how, with her need to love and her ambiguous orientation, she would find love in the enclosed atmosphere of a women's war-time service" (Raymond, n.d.: 182).

In fact, Frankau's narrative makes it clear that she had been attracted to Vernon since their first meeting, some fourteen or fifteen years earlier, a meeting which pre-dated Frankau's relationship with Humbert Wolfe:

What I had to admit to myself whenever we met would have embarrassed you. So I never said it and must say it now. The thing that you have for me is romance.

Romance is a word cheapened and hollowed by its associations, but I do not know a better substitute. I found romance in you, from the first time that I looked at you, a stranger in a familiar room, and realised how much your face interested me.

It is not a face that belongs to this century at all; it is too generous; the lights are too vivid, the shadows too smoky; its whole trend is at the same time too vulnerable and too gay. The pictures of your ancestors have this look; some of them must have had your temperament. (Frankau, n.d.: 7) 
Vernon's temperament informs her "unorthodox, vital" style of working, about which Frankau writes appreciatively:

There were others, at Commands and at Districts, who had more obvious qualifications; whose work was more meticulous, more definable or more impressive on paper. But they did not flick the whiplash of enthusiasm across my shoulders that you did. ... The instant effect of beginning to work with you was to drink a huge draught of energy and to see the horizon widened. (38)

Frankau's decisions to join the ATS and to become a Roman Catholic are clearly influenced by Vernon's example:

You guided my way to the Church. You turned me from a would-be sybarite into a would-be soldier. ...

You were something that I have not known before and shall not know again; a thing that a woman is not expected to know; my comrade-inarms. .... You gave me the Army and the Army gave me that. (71-2)

The relationship evidently meets with some hostility from their Army colleagues and superiors, however, beginning with a lengthy wrangle over Vernon's request to transfer to Frankau's branch. As Frankau puts it, "the machinery that operated our destinies began to misbehave. It became noticeably human and feminine machinery; it did not look so pretty that way" (35). At one point Vernon is given sick leave, "less because you needed it (and you did) than 
because they could not decide to let you go and had meantime posted somebody to take your place" (35). When Vernon's transfer request is finally granted, the two women are immediately posted two hundred miles apart. Despite this, they spend much of 1943 working together on Army Education courses around the country. Early in 1944, however, Vernon's failing health results in her being demoted and placed on the Y-list, the category for ineffective personnel not yet discharged from the service; she is warned that another attack will mean a discharge on medical grounds.

In the light of recent scholarship, these apparently separate events - the reposting and Vernon's demotion and Y-listing - form a pattern. As Emma Vickers notes in her study of same-sex relationships in the British Armed Forces 1939-45, reposting and discharge on medical grounds were two of the official ways of dealing with lesbian relationships in the Women's Services. "Unlike their male counterparts, servicewomen could not be punished for same-sex activity under either civilian or military law" (Vickers, 2013, 106). The need for womanpower in wartime, she argues, meant that such relationships were likely to be ignored by the authorities unless they were seen as disruptive or posing a disciplinary problem (123-4). Despite widespread public concern about the effect of Service life, especially in the ATS, on women's sexual morality (Summerfield and Crockett, 1992), Lesley A. Hall notes that fears about lesbianism were "surprisingly muted" (Hall, 2000/2013: 125). There was no official guidance on the matter until Letitia Fairfield's 1943 document "A Special Problem"; even after this, Vickers notes, there was "an unwillingness to lecture women openly on the subject in case it occasioned 'too much talk'” (Vickers, 
2013: 122, quoting Fairfield). Fairfield, formerly the senior woman doctor to the Army, advised that women "sharing an excessive attachment" should be reposted if they could not be "diverted by other interests", or if their behavior was causing gossip and scandal, which she saw as more dangerous than most actual lesbian relationships. ${ }^{v}$ Only in extreme cases should a lesbian be discharged from the Service. Vickers notes that one option for dealing with such cases was a medical discharge which labeled women as "Services No Longer Required" and that this makes it difficult to establish how many women were discharged because of their lesbianism (Vickers, 2013: 136). Given the desire to avoid "too much talk", this difficulty seems deliberate. As Rebecca Jennings notes in her lesbian history of post-war Britain, “statements issued by the women's services attempted to downplay the significance of their anti-lesbian policy, arguing that it rarely needed to be brought into force" (Jennings, 2007: 69). Albertine Winner, medical consultant to the Women's Services, insisted that lesbianism had not been an important problem in the ATS: "A certain number of minor cases arose of unwise friendships, most of which were dealt with by judicious posting of the culprits. A very small number indeed of serious cases came to light, mostly centring round a promiscuous psychopath, and, in the same Service, only some half-dozen women had to be discharged on these grounds out of nearly a quarter of a million who passed through our hands." (Winner, 1947: 6).vi As Jennings suggests, however, Winner's phrase "a promiscuous psychopath" reinforces the sense of the lesbian as "a predatory and disruptive force" (Jennings, 2007: 70).

Did the ATS regard Frankau and Vernon's relationship as a disciplinary problem? It's impossible to know for sure, but their treatment by the Army - reposting, the 
threat of discharge on medical grounds - is precisely how the women's services dealt with disruptive lesbian relationships. Frankau remarks that she and Vernon "never tamed the whole of our natural wildness; in work as in our leisure we still kicked over the traces and made people cross" (40). Vernon's health problems were real, and increasingly serious, but they were also convenient for the Army, here as in the row about her transfer.

Vernon's renewed hospitalization in June 1944 effectively ends her Army career, confronting Frankau with a decision about her own future: "When I thought of 'us' it was like thinking of a third person. "Us" was made up of you and me and the Army and our house in Pimlico. ... And this was the end of the workpartnership. ... How much of 'us' would go on when that was no longer shareable?" (47). Frankau decides to return to duty, leaving Vernon convalescing in Wales. Five days before their expected reunion, Vernon has a stroke that proves fatal.

The narrative gives a haunting account of Frankau's overnight journey from London to the military hospital in Wales, ending with the discovery that she has come too late to see Vernon alive:

The train got to Caernarvon at six o'clock the next morning. I had slept for a few minutes, just before Crewe, and in those few minutes we said goodbye. I remember little except that we were very close and that I knew what it was all about. I woke, thinking "Rubbish. I shall find you and you will have recovered consciousness and I'll stay with you all the time." 
Paralysed on one side. Would that last? What then. I was very noisy and very gay with the other people in the carriage all the way down.

... The morning was very clear and fine. Flights of wild duck, heron, and birds that I did not recognise kept flying over. I felt light and well, full of curiosity. I sent messages to you as I walked. "Here I am," I shouted, "Wait for me. I couldn't get here any quicker."

It was easy, it was familiar, this walk with the beauty of the land, the birds and the early sun. I had always known about it, somewhere, sometime. I puzzled my way among shrubs and stable-buildings until I found the main door. An orderly who was washing the hall went to find somebody. No, they said, you were not here; there was no A.T.S. officer here. So I went into the small box of a room beside the door, and this time I got through to Harlech and they told me that you were dead; you had died ten minutes after admission (Frankau, n.d.: 58-9).

Frankau draws an explicit parallel between her experience of Humbert Wolfe's death and of Vernon's:

I looked down at your face and saw that all the lights and shadows that made its liveliness were gone; you did not look vulnerable, nor gay, only quiet. At first sight you were unrelated to the person whom I had last seen, then completely familiar and logical. It was my second chance in five years to look upon the change from life to death in somebody whom I had loved; I had forgotten the logical nature of this different look. Now I know 
again. And I saw that though this was not you, it was the tired body of you, and I had seen you very tired, but not so tired as this. (61)

The paralleling of the two deaths here is significant. Frankau's 1935 memoir, I Find Four People, had ended with her identifying the body of her much loved great-aunt, Eliza Aria, but that is not the experience she recalls in "the change from life to death in somebody whom I had loved." The death of Humbert, called " $\mathrm{H}$ " in the unpublished narrative, is seen as the same kind of loss as the death of Vernon. This time, Frankau is determined to learn the lessons of mourning that she failed to learn after Humbert's death, not to run away from her grief: "So I mourn you in the places where we went together, and I thank you for the second chance" (71).

Frankau does not explicitly identify either Humbert or Vernon as a lover, here or elsewhere in the narrative. Indeed, she writes that she and Vernon "weren't like two lovers, who never knew an unhappy moment together nor spoke an angry word" (71). Given the moral climate in which she was writing, her caution is not surprising. Nevertheless their established relationship is clear from Frankau's status as Vernon's next-of-kin, deciding about the post-mortem, arranging the funeral and burial, and as her main beneficiary. It is also evident in the reactions of people who saw them as a couple, including the regulars at their local bar:

...The woman came in and we said Good-evening; You'll remember her, she was the one with the daughter in the W.R.N.S., the one who didn't buy the fur coat. 
"You're always alone now" she said, "What's happened to your friend?" I am getting used to this one and I repeated my formula "You didn't hear about that?"

"No." But like the others, she had got it before I said "She died in August."

I looked at the pretty, ordinary little face and saw it begin to quiver and crumple. She said how much she liked you, how much everybody liked you; how awful this must be for me.

"Well, it is and it isn't," I said stupidly, "I'm quite all right, you know." “That's a thing I've always wanted and never had," she said.

"What is?"

"A great friend; a woman friend. I've always thought how lovely it must be. I used to think so when I saw you two together. You must miss her.["]

"I do. All the time." (70)

The mixture of desperate sadness and touching validation here is powerful and characteristic of Frankau: the vignette opens up a bleak world of loneliness and longing for intimacy, but one which is nevertheless illuminated by the recognition of love.

Frankau's autograph manuscript of the narrative does not survive. In Pen to Paper: A Novelist's Notebook (1961), she explains that her normal method of working is to produce two handwritten drafts, the Rough and the Smooth, and then to employ the services of a typist. It's not clear where or when the typed 
manuscript, which runs to some seventy-seven pages of foolscap, was produced. There are some handwritten corrections of errors and occasional small changes of phrasing. Internal evidence suggests that she finished writing the narrative early in 1945, but there is no record of her seeking a publisher for it until late in 1946.

Frankau's life by this point had undergone a series of significant changes: the death of her mother in May 1945; her marriage to an American, Marshall Dill Junior, in October 1945; Marshall's return to California and insistence that she join him there; and the death of their child, born prematurely in July 1946 a matter of days after Frankau's reluctant journey by air to the USA. In a radio broadcast of 1964, Frankau said that she had married "largely in order to have children not because I loved my husband. I was fond of him but I wasn't in love with him and as an emotional type I should never have tried to be sensible" (quoted in Raymond, n.d.: 197-8). Robin Maugham, who introduced Frankau to Marshall and was the groom's usher at the wedding, had had an affair with Marshall himself (d'Arch Smith, 2015: 58). The marriage was already in trouble by the autumn of 1946, and Frankau would later describe this period as "a time of dark unhappiness" (Raymond, n.d.: 206). Why she returned to the narrative about Vernon at this point is not clear, but she accepted Louise Callender's advice to put it aside, and continued her work on the new novel, Shaken in the Wind, in which aspects of her current situation - the death of a difficult parent, a postwar marriage to an American, and an unhappy forced relocation to California - would all make an appearance. 
Though Frankau never published the narrative, material from it appears in her later fiction. In The Bridge (1957), the novelist David's memoir of his dead daughter, Anne, borrows the narrative's conversational form and takes its title, $A$ Pause in the Conversation, from Frankau's words to Vernon about death: "This is only a pause in our conversation" (Frankau, n.d.: 77). In Shaken in the Wind, Vernon's Ludlow childhood becomes Cynthia's, and quotations abound from the talismanic book of poetry Vernon and Frankau shared, John Brown's Body by Stephen Vincent Benét. This is the book in which Stuart leaves the note saying "Please love me", but it is also associated with Cynthia's dead lover, Ricky. Ricky quotes to Cynthia the same lines Vernon had quoted to Frankau, saying that the poet might have written them for her:

$$
\begin{aligned}
& \text { "I can drink the midnight out } \\
& \text { and rise empty, having dined, } \\
& \text { for my courage and my doubt } \\
& \text { are a double strand of mind }
\end{aligned}
$$$$
\text { and too subtly intertwined." (Frankau, n.d.: 73; Frankau, 1948: 25) }
$$

Aspects of Frankau's unpublished narrative recur most obviously in her fictional accounts of all-female organizations during the Second World War: the ATS in her most famous novel, The Willow Cabin (1949) and the ambulance-corps in her last completed work, Over the Mountains (1967). In The Willow Cabin, Caroline Seward, working as an ATS instructor, is drawn to a young cadet, Vale: It was impossible not to feel instincts of favouritism towards Vale, who had a lively mind and a dark boyish beauty; she was the most vivid person in the platoon; she talked Caroline's language; like the potential favourites on 
other courses, she received carefully anonymous treatment. (Frankau, 1949/1951: 163)

It's obviously not the first time this has happened, but it's equally obvious that the attraction is mutual. When Vale suggests an outing to a local bar, Caroline finds herself

irritated because she was thinking "It would be fun to go to the Aperitif with you." Again she saw the danger-line of this incarceration among women; the school-atmosphere breeding emotion where none should exist.

The last sentence recalls Fairfield's view of lesbianism as "essentially the persistence of an immature mental and emotional phase", or Winner's description of same-sex relationships as "an arrest of normal sexual development at an adolescent stage" (Winner, 1947: 3-4).vii The schoolatmosphere in The Willow Cabin is a less happy version of Vernon's note to Frankau on her arrival at the Platoon HQ, housed in a former school, "Welcome to the Lower Fourth," a greeting which makes Frankau grin because it is "in keeping with us" (Frankau, n.d.: 5). Though she rejects the idea of "arrested development" ("On serious issues, yours is the most adult mind I know"), she accepts their "joint childishness" as part of what draws her and Vernon together: It is not, I suppose, suitable to two unmarried women in their middle thirties. But I cannot think of me as an unmarried woman in my middle thirties, any more than I can put that label on you.

When I think of you, of me, or of us, we have no age and no sex. We are two animals made up of several sorts of characteristic; alike in that we are 
wild and irritating and much too quick on the draw. We are always noticeable, frequently wrong, seldom negative. (5)

Some of the most unambiguously lesbian characters in Frankau's later fiction clearly have links to Vernon: the ATS officer Valentine Brooks in The Bridge, for example, described as "A large, vivid woman in khaki... Merry-eyed and foulmouthed" (Frankau, 1957: 88). "Valentine roared with laughter; she looked like Charles the Second when she laughed; black curls, grape-bloom eyes and white teeth" (Frankau, 1957: 89). Valentine's attitude, "what have you got to give to a war except you?" (Frankau, 1957: 89) recalls Vernon's, in that conversation in December 1941 that led to Frankau's decision to join the ATS: “Do you remember, Vernon? 'So what, you die for it?' and, 'All that you have got, to give, is you."' (Frankau, n.d.: 10). Valentine is unrequitedly in love with the bisexual Linda, who is married to David. He watches Valentine "take Linda into her arms with a man's embrace; he thought that Linda rather liked it." (Frankau, 1957: 90). Vernon's personality echoes in Valentine's self-description to David: "I'll always be in love with Linda, you know that, but our heads don't work the same way. I haven't the patience to analyse it all and make little measured judgments and hold to them. I'm a gambler; and a sloppy type; and what's good enough for my buddies is good enough for me" (Frankau, 1957: 91).

In Over the Mountains, traces of Vernon appear in Noel, one of two rival lesbians running a women's ambulance-corps in wartime France. Noel's gender-neutral name is actually her surname; her first name is never revealed. Dashing and charismatic, both a leader and a rebel, she shares Vernon's ability to inspire her 
troops: "A magician who could direct other people without seeming to do a stroke of work herself, she organized her devout band with smooth efficiency" (Frankau, 1967: 60-61). Rab Lee, who falls in love with Noel, sees her as "'the Pied Piper... Follow - follow - follow. When she laughs, you laugh too. When she takes something seriously you go after it.' (The book, John Brown's Body, was a case in point.)" (Frankau, 1967: 61).

Noel is a more powerful but also a more sinister figure than Valentine Brooks: a slash of a knife at her Caesarian birth has given her a face that's half-ordinary, half-demonic (Frankau, 1967: 60-1). A serial seducer with a practiced technique, she comes close to being Albertine Winner's idea of the lesbian as "promiscuous psychopath". Rab feels violent ambivalence after being seduced by her: "How can I love her and hate her at the same time?" (Frankau, 1967: 74). Torn between Noel and the novel's hero, Thomas, Rab is "scared of the choice, guilty and awed and excited and miserable, hating and loving" (Frankau, 1967: 75). But Rab doesn't get to make the choice; the narrative makes it for her. Noel is killed and Rab is left blaming herself for not being there. Believing that Thomas is dead too, she tells his sister, Sarah, "I loved him. I'd have loved Noel more, though, given half a chance" (Frankau, 1967: 271). The only way she can deal with her grief for Noel is by "slamming the door on all that, here and now" (Frankau, 1967: 273).

If Frankau can't give Rab that "half a chance" to love another woman, even in a novel published in 1967, in the unpublished narrative she is able to honour her relationship with Vernon, to take it seriously. It is a partnership, clearly, and it is love. Diana Raymond described the narrative as "this rather strange 
unpublished long story... it's a lament for her - it's fiction so I don't know how much it's actually true to life."viii Louise Callender's reaction - "almost too personal for publication" - suggests that Heinemann didn't think this was fiction at all.

It would be easy to overvalue the unpublished narrative precisely because it's unpublished, to see it as inherently more truthful and revealing, or conclude that the relationship with Vernon must be the key to Frankau's life and works; I don't want to do that. In addition to her formative relationship with Humbert Wolfe and her ill-fated marriage, Frankau had two other long-term relationships with women besides Vernon: the writer and actress Ethel Harriman Russell (18971953), whom Marshall blamed for the break-up of the marriage; and the theatre producer and director Margaret (Peggy) Webster (1905-72), a relationship Webster described as "fourteen years of total happiness" (Webster, 1972: 274). But the relationship with Vernon was clearly important to Frankau, and has been insufficiently acknowledged as such.

\section{Diana Raymond's essay on Frankau for the Oxford Dictionary of National} Biography doesn't name Vernon, possibly for fear of offending any surviving relations, but briefly mentions Frankau's relationship with "a fellow woman officer in the ATS" (Raymond, 2004). Raymond never met Vernon, and Frankau didn't talk to her about the relationship. ix The biography's account of Vernon is based on the often hostile testimony of Frankau's friends. Pat Frere remembered Vernon chiefly as a drunk, while other friends complained of her gatecrashing their meetings with Frankau: "Pamela arrived in uniform with this unknown 
fellow officer, who not only stayed the whole evening, but for the night too" (Raymond, n.d.: 182). Albertine Winner, interviewed in the last weeks of her life, expressed her "extreme dislike" for Vernon: "at the mention of Vernon she sat up and said that Vernon had been an unattractive woman who 'sponged on Pam' and was unworthy of her" (Raymond, n.d.: 181). Winner herself was clearly attracted to Frankau, and Raymond suggests she may have been jealous of Vernon (Raymond, n.d. 181). Written at a time when the narrative was believed to be lost, Raymond's biography shortchanges the relationship with Vernon, and the significance of her death for Frankau:

A small shadow at a time when war was at its height... But for Pamela, never entirely healed from the loss of Humbert, it was large...

It could not, in the nature of things, have the force of Humbert's death: the affair had not lasted so long, and Vernon, by all accounts, was no Humbert. But it was the death of someone on whom she had lavished all her love, and it revived echoes of that other pulverizing death. (Raymond, n.d.: 188-9).

When the narrative was rediscovered in Heinemann's basement, Raymond annotated the typescript of her biography: "This unpublished work has now come to light, so some re-writing would be needed here" (Raymond, n.d.: 189). Presumably this refers to the paragraph stating that the work "cannot now be traced" and that it has been "variously described as an untitled book, an essay or a short story" (Raymond, n.d.: 189). Raymond remained somewhat puzzled by Frankau's attraction to Vernon: "Pamela wrote you know very powerfully of her 
so there must have been something there."x It is clear that more of the record of Pamela Frankau's life and work needs to be rewritten in the light of the unpublished narrative.

What would the record of Frankau's life have looked like if Heinemann had agreed to publish her lament for Vernon? It would have been much more difficult to maintain that her one great love was Humbert Wolfe, for a start. Frankau told Diana Raymond that "the first half of her life was men and the second half was women."xi But the second half of her life was also where her best writing happened, the books that came harder to her but that she valued more, and rightly so. Diana Raymond said that "It all came back with The Willow Cabin", and that's true, but the unpublished narrative marks the beginning of that return, and of a new stage of writing. xii The fact that The Willow Cabin is dedicated jointly to the memory of Frankau's mother, Humbert and Vernon (all three indicated only by initials), needs to be acknowledged for what it is: these are the three significant losses of Frankau's life to date, and they all inform how she writes about grief. G.B. Stern, a fellow novelist and close friend, said of Frankau that "She has a rare talent, in her fiction, for reaching down to pain and suffering so that vicariously it hurts" (Stern, 1957: 99), a statement akin to Louise Callender's comment on the untitled narrative: "every one of the author's emotions comes blazing through with the utmost vividness."

This is, then, in part a story about the value that the world places on lesbian love and lesbian loves. About how we count, or how we don't. About how our relationships are acknowledged, or not. By ourselves; by our families and 
friends; by our colleagues; by institutions and officials; and by the makers of records, official and unofficial, biographers and critics and historians. Frankau's narrative of love and loss in wartime treats Humbert's death and Vernon's as equal losses. In doing so, she values those different loves equally too. Over seventy years later, we're still waiting for the world to do the same. 


\section{REFERENCES}

d'Arch Smith, Timothy. (2015). The Frankaus: Prejudice and Principles within a London Literary Family, Norwich: Michael Russell.

Elston, M.A. (2004). “Fairfield, (Josephine) Letitia Denny (1885-1978)”, Oxford

Dictionary of National Biography, Oxford University Press, available online at http://www.oxforddnb.com/view/article/54196, accessed 21 September 2017.

Endelman, Todd M. (1994). The Frankaus of London: A Study in Radical Assimilation. Jewish History, 8:1-2, 117-54.

Frankau, Pamela. (1935/1938). I Find Four People, London: Penguin.

Frankau, Pamela. (n.d.). untitled, unpublished typescript.

Frankau, Pamela. (1948). Shaken in the Wind, London: Heinemann.

Frankau, Pamela. (1949/1951). The Willow Cabin, reprinted London: The Reprint Society.

Frankau, Pamela. (1957). The Bridge, London: Heinemann.

Frankau, Pamela. (1961). Pen to Paper: A novelist's notebook, London:

Heinemann. 
Frankau, Pamela. (1967). Over the mountains, London: Heinemann.

Gonda, Caroline. (2009). "A Roller-coaster of a Life with Everything in it":

Pamela Frankau (1908-67)" in Jewish/Christian/Queer: Crossroads and Identities, ed. Frederick S. Roden, Farnham: Ashgate, 181-203.

Hall, Lesley A. (2000; 2013). Sex, Gender and Social Change in Britain since 1880, Houndmills, Basingstoke: Palgrave Macmillan.

Jennings, Rebecca. (2007). Tomboys and Bachelor Girls: A lesbian history of postwar Britain 1945-71, Manchester: Manchester University Press.

Raymond, Diana. (n.d.). Pamela Frankau, A Life (1908-1967), unpublished typescript.

Raymond, Diana. (2004). “Frankau, Pamela Sydney (1908-1967)”, Oxford Dictionary of National Biography, Oxford University Press, available online at http://www.oxforddnb.com/view/article/58791, accessed 21 September 2017.

Saunders, Cicely. (2004) “Winner, Dame Albertine Louisa (1907-1988)”, Oxford Dictionary of National Biography, Oxford University Press, available online at http://www.oxforddnb.com/view/article/39877, accessed 21 September 2017. 
Stern, G.B. (1957). ...And did he stop and speak to you?, London: Coram in association with Centaur Press.

Summerfield, Penny, and Crockett, Nicole. (1992). "You Weren't Taught that with the Welding": Lessons in Sexuality in the Second World War. Women's History Review 3, 435-454.

Vickers, Emma. (2013). Queen and Country: Same-Sex Desire in the British Armed Forces, 1939-45, Manchester: Manchester UP.

Webster, Margaret. (1972). Don't Put Your Daughter on the Stage, New York: Knopf.

Winner, Albertine. (1947). Homosexuality in Women, pamphlet reprinted from Medical Press 217: 5652, 3-7.

${ }^{\text {i }}$ Louise Callender, letter to W.P. Watt, December 12, 1946.

ii W.P. Watt, letter to Louise Callender, February 6, 1947.

iii I am grateful to Timothy d'Arch Smith for giving me access to Frankau's narrative and to the correspondence between her agent and Heinemann. Thanks 
to him I was also able to interview Diana Raymond, and to read the typescript of her unpublished biography of Frankau.

iv On the Frankau family, see also Endelman (1994).

v London Metropolitan Archives LCC/PH/GEN/3/19: Papers of Letitia Fairfield, Homosexuality, 1947-61, “A Special Problem-Written during the War by Dr Letitia Fairfield for the guidance of the Officers in the Women's Services," 1943. On Fairfield's career, see Elston (2004).

vi On Winner's career, see Saunders (2004).

vii London Metropolitan Archives LCC/PH/GEN/3/19: Fairfield, “A Special Problem," 1943; see also Vickers (2013), 130-1. On Winner's interpretation of lesbianism as arrested development, see Jennings (2007), 36-7. viii Diana Raymond, interviewed by author, 2008.

ix Raymond, interviewed by author, 2008.

x Raymond, interviewed by author, 2008.

xi Raymond, interviewed by author, 2008.

xii Raymond, interviewed by author, 2008. 